\title{
Structure of $1^{\prime}$-(p-Bromophenyl)-3' -ethyl-1', $3^{\prime}, 4^{\prime}, 5^{\prime}$-tetrahydro-1,2-dideoxy-D-glycero-D- gulo-heptofuranoso[1,2-d $]_{\text {imidazole-2' }}$-thione, ${ }^{*} \mathrm{C}_{16} \mathrm{H}_{21} \mathrm{BrN}_{2} \mathrm{O}_{5} \mathrm{~S}$
}

\author{
By M. D. Estrada, A. Conde AND R. MÁrquez \\ Departamento de Física del Estado Sólido, Facultad de Física, Universidad de Sevilla, Spain
}

(Received 14 September 1983; accepted 1 February 1984)

Abstract. $M_{r}=433.3$, monoclinic, $P 2_{1}, a=6.924(3)$, $b=8.661$ (1), $c=15.039$ (3) $\AA, \beta=96.92(3)^{\circ}, V=$ $895.3(4) \AA^{3}, \quad Z=2, \quad D_{m}=1.598(5), \quad D_{x}=$ $1.607 \mathrm{Mg} \mathrm{m}^{-3}$, Mo $K \alpha, \lambda=0.7107 \AA, \mu=2.42 \mathrm{~mm}^{-1}$, $F(000)=444, T=300 \mathrm{~K}, R=0.039$ for 2038 observed independent reflexions. The sugar ring adopts a ${ }^{4} E$ conformation and the dihedral angle in the bicycle is $49.0(2)^{\circ}$. Intermolecular hydrogen bonds link the molecules to form a three-dimensional network.

Introduction. The structure determination of the title compound (I) was undertaken as part of a continuing research project in this laboratory involving glucimidazoles and imidazole $C$-nucleosides. Compounds obtained by reaction of 2-deoxy-2-ethyl(propyl)aminohexose(heptose) with aryl (alkyl) isothiocyanates (Garcia Gonzalez, Galbis-Pérez, FernandezGarcia-Hierro \& Fernández-Bolaños, 1979; GalbisPérez, Pinto Corraliza, Román-Galán \& GomézGuillen, 1979) have been studied in order to establish the conformational details of the molecule in the solid state. Recently, we have reported the crystal structure of $1^{\prime}$-( $p$-bromophenyl)-3'-ethyl-1',3',4',5'-tetrahydro1,2-dideoxy-D-glycero-L-gluco-heptofuranoso[ 1,2-d] imidazole-2'-thione (Estrada, Conde \& Márquez, 1983). The title compound has been prepared (GalbisPérez, Palacios, Jiménez-Requejo, Avalos \& Fernández-Bolaños, 1983) by condensation of 2-amino2-deoxy-D-glycero-D-gluco-heptose with aryl isothiocyanate (Galbis-Pérez et al., 1979) and separated by fractioned crystallization. Its chemical nature was established from elemental analysis and spectroscopic data and the X-ray analysis was carried out to define its structure and conformation.

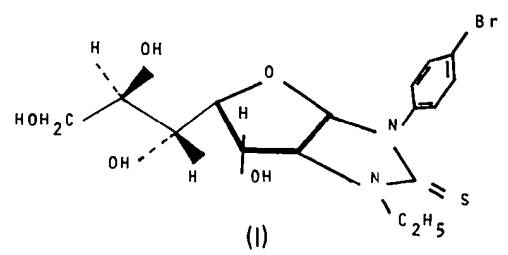

* IUPAC name: 6-(p-bromophenyl)-4-ethyl-3-hydroxy-2-(1,2,3trihydroxypropyl)-2,3,3a,5,6,6a-hexahydrofuro[ $2,3-d]$ imidazole$5(4 H)$-thione.

$0108-2701 / 84 / 050898-04 \$ 01.50$
Experimental. Single crystals in the form of prisms elongated along [001] prepared in the Organic Chemistry Department of the University of Extremadura and kindly supplied by Professor J. Galbis. $D_{m}$ by flotation method. Crystal $0.06 \times 0.08 \times 0.13 \mathrm{~mm}$. Unit-cell parameters by least squares from 23 reflexions, $5<$ $\theta<20^{\circ}$. Enraf-Nonius CAD-4 diffractometer, graphite monochromator, $2 \theta \leq 60^{\circ}(|h| \leq 9, k \leq 12$, $l \leq 21), \omega-2 \theta$ scan mode. Three standard reflexions $(200,020,023)$ : variation in intensity less than $3 \%$ of mean value. 2855 independent reflexions measured, 817 considered unobserved $[I<2 \sigma(I)]$. Lorentz and polarization correction, no correction for absorption $(\mu R \sim 0.2)$ or extinction. Patterson function and heavyatom method with the initial set of phases based on $\mathrm{Br}$-atom position. Full-matrix least-squares refinement on $F$, anisotropic. Difference Fourier synthesis revealed the $21 \mathrm{H}$-atom positions; isotropic temperature factor for each $\mathrm{H}$ set equal to that of the atom bonded to it. Further least-squares refinement including the positional parameters of the $\mathrm{H}$ atoms and anomalous-dispersion corrections for $\mathrm{Br}$ and $\mathrm{S}$ atomic scattering factors (International Tables for X-ray Crystallography, 1974)

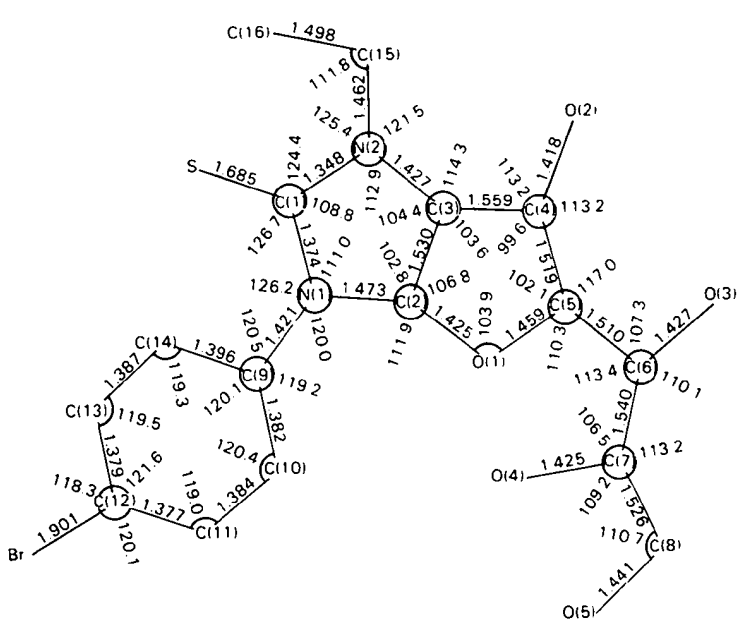

Fig. 1. Bond lengths $(\AA)$ and angles $\left(^{\circ}\right)$ in the molecule. (Standard deviations are in the ranges $0.006-0.010 \AA$ and $0.41-0.60^{\circ}$, respectively.)

(c) 1984 International Union of Crystallography 
Table 1. Atomic coordinates $\left(\times 10^{4}\right)$ and equivalent isotropic temperature factors

\begin{tabular}{lrccc}
\multicolumn{5}{c}{$U_{\text {eq }}=\frac{1}{3} \sum_{i} \sum_{j} U_{i j} a_{i}^{*} a_{j}^{*} a_{i} a_{j} \cos \left(\mathbf{a}_{i}, \mathbf{a}_{j}\right)\left(\times 10^{3}\right)$} \\
$\mathrm{Br}$ & $x$ & $y$ & $z$ & $U_{\text {eq }}\left(\AA^{2}\right)$ \\
$\mathrm{S}$ & $8953(1)$ & 0 & $57(5)$ & $54(<1)$ \\
$\mathrm{O}(1)$ & $4655(2)$ & $-6296(2)$ & $-2391(1)$ & $36(1)$ \\
$\mathrm{O}(2)$ & $263(5)$ & $-1949(5)$ & $-2955(3)$ & $32(1)$ \\
$\mathrm{O}(3)$ & $-707(6)$ & $-4450(5)$ & $-4227(3)$ & $35(1)$ \\
$\mathrm{O}(4)$ & $-2427(6)$ & $272(6)$ & $-3888(3)$ & $43(1)$ \\
$\mathrm{O}(5)$ & $-4409(7)$ & $-724(6)$ & $-5485(3)$ & $44(2)$ \\
$\mathrm{N}(1)$ & $-7587(6)$ & $-2267(6)$ & $-4841(3)$ & $42(2)$ \\
$\mathrm{N}(2)$ & $2613(6)$ & $-3648(6)$ & $-2162(3)$ & $27(1)$ \\
$\mathrm{C}(1)$ & $822(7)$ & $-5679(6)$ & $-2619(4)$ & $32(2)$ \\
$\mathrm{C}(2)$ & $2658(7)$ & $-5187(7)$ & $-2380(3)$ & $27(2)$ \\
$\mathrm{C}(3)$ & $599(7)$ & $-3065(7)$ & $-2257(4)$ & $27(2)$ \\
$\mathrm{C}(4)$ & $-594(7)$ & $-4494(7)$ & $-2568(4)$ & $27(2)$ \\
$\mathrm{C}(5)$ & $-1683(7)$ & $-4000(7)$ & $-3492(4)$ & $27(2)$ \\
$\mathrm{C}(6)$ & $-1722(7)$ & $-2263(7)$ & $-3357(4)$ & $28(2)$ \\
$\mathrm{C}(7)$ & $-2224(8)$ & $-1280(8)$ & $-4182(4)$ & $29(2)$ \\
$\mathrm{C}(8)$ & $-4093(8)$ & $-1798(7)$ & $-4764(4)$ & $30(2)$ \\
$\mathrm{C}(9)$ & $-5874(8)$ & $-1820(9)$ & $-4257(4)$ & $7(2)$ \\
$\mathrm{C}(10)$ & $4114(7)$ & $-2808(7)$ & $-1645(4)$ & $1(2)$ \\
$\mathrm{C}(11)$ & $4287(8)$ & $-1242(8)$ & $-1791(4)$ & $1(2)$ \\
$\mathrm{C}(12)$ & $5708(9)$ & $-389(7)$ & $-1284(4)$ & $1(2)$ \\
$\mathrm{C}(13)$ & $6922(8)$ & $-1119(8)$ & $-622(4)$ & $1(2)$ \\
$\mathrm{C}(14)$ & $6742(9)$ & $-2673(8)$ & $-449(4)$ & $0(2)$ \\
$\mathrm{C}(15)$ & $5315(8)$ & $-3529(8)$ & $-955(4)$ & $34(2)$ \\
$\mathrm{C}(16)$ & $253(9)$ & $-7267(8)$ & $-2855(4)$ & $37(2)$ \\
& $-3(11)$ & $-8214(9)$ & $-2044(5)$ & $49(2)$
\end{tabular}

reduced $R_{w}$ to $0.051 \quad(R=0.049)$; weighting scheme based on a statistical count criterion $\left(w=1 / \sigma^{2}\right)$. $(\Delta / \sigma)_{\max }=0 \cdot 3 . S=1.09$ for 289 refined parameters. Final difference synthesis showed $0.35 \geq \Delta \rho \geq$ $-0.25 \mathrm{e} \AA^{-3}$. The enantiomorphic form of the molecule was considered and the final $R_{w}$ value was $0.041(R=0.039)$. The application of the $\mathscr{R}$ test (Hamilton, 1965) indicates that the second enantiomorph is correct $\left[\mathscr{R}=R_{w}(1) / R_{w}(2)=1 \cdot 244\right.$; $\mathscr{R}_{1,1749,0.005} \simeq 1 \cdot 002$ ] and, therefore, can be retained as the absolute configuration. Crystallographic programs of the XRAY70 system (Stewart, Kundell \& Baldwin, 1970) used throughout.

Discussion. Fractional atomic coordinates and equivalent isotropic temperature factors (Hamilton, 1959) for non-hydrogen atoms are given in Table 1.* Bond lengths and angles involving non-hydrogen atoms are shown in Fig. 1. $\mathrm{C}-\mathrm{H}$ bond distances range from 0.83 (9) to 1.15 (9) $\AA$ with an average value of 1.03 (9) $\AA$. The average $\mathrm{O}-\mathrm{H}$ bond length is $0.92(9) \AA$.

\section{Molecular geometry}

Values of bond lengths and angles in the imidazolidine ring are similar to those reported in other

* Lists of structure factors, anisotropic thermal parameters and $\mathrm{H}$-atom parameters have been deposited with the British Library Lending Division as Supplementary Publication No. SUP 39192 (14 pp.). Copies may be obtained through The Executive Secretary, International Union of Crystallography, 5 Abbey Square, Chester CH1 2HU, England. analogous compounds (Conde, Bernier \& Márquez, 1980; Estrada, Conde \& Márquez, 1983). The typical asymmetry for intracyclic $\mathrm{N}-\mathrm{C}$ bonds, due to the contribution of the different resonance forms of the thiourea systems (Valle, Cojazzi, Bussetti \& Mammi 1970; Estrada, Conde \& Márquez, 1983), is observed. The ring is planar as indicated by the $\sum(\Delta / \sigma)^{2}$ value of $0.94\left(\chi^{2}\right.$ at $\left.95 \% 5.59\right)$.

Bond lengths and angles in the furanosyl ring are similar to those observed in analogous compounds previously studied and the typical asymmetry of the endocyclic bonds $\mathrm{O}(1)-\mathrm{C}(2)$ and $\mathrm{O}(1)-\mathrm{C}(5)$ due to anomeric effects is observed. The glucofuranose ring is not planar as expected. In terms of the ring-puckering coordinates (Cremer \& Pople, 1975) the amplitude and phase magnitudes are $Q=0.462(5) \AA$ and $\varphi=$ $145.2(6)^{\circ}$ for the sequence $\mathrm{O}(1)-\mathrm{C}(2)-\mathrm{C}(3)-\mathrm{C}(4)-$ $\mathrm{C}(5)$ and the resulting conformation is ${ }^{4} E$. The asymmetry parameter of Duax, Weeks \& Rohrer (1976) is $\Delta C_{s}[\mathrm{C}(5)]=0.014(3)^{\circ}$. This puckering mode is different from the twist conformation found in a recently reported analogous compound (Estrada, Conde \& Márquez, 1983) but it is similar to those of other analogous compounds (Conde, López-Castro \& Márquez, 1978). The small value of the $\mathrm{C}(4)-\mathrm{C}(3)-$ $\mathrm{C}(2)-\mathrm{O}(1)$ torsion angle $\left[-2.4(5)^{\circ}\right]$, characteristic of these compounds, is attributed to distortion of the furanosyl ring due to the ring fusion.

The two rings in the bicycle show a cis form of coupling as illustrated in Fig. 2 in which $v_{1}$ and $\mu_{1}$ are projected valency angles and $\beta, \gamma$ and $\delta$ torsion angles. The relation $\beta=\gamma$ derived for a cis fusion involving only ternary or quaternary $\mathrm{C}$ atoms (Geise, Altona \& Romers, 1967) holds in this case. As observed in analogous compounds (Conde, López-Castro \& Márquez, 1978; Conde, Bernier \& Márquez, 1980; Estrada, Conde \& Márquez, 1983) the bonds of the C(2) and $\mathrm{C}(3)$ carbon atoms are nearly eclipsed. The dihedral angle between the least-squares planes of the imidazolidine and furanosyl rings is $49 \cdot 3(3)^{\circ}$. This value is smaller than those found for similar compounds $\left(\sim 70^{\circ}\right)$. In the phenyl ring, the atomic deviations from the least-squares plane through the ring atoms are

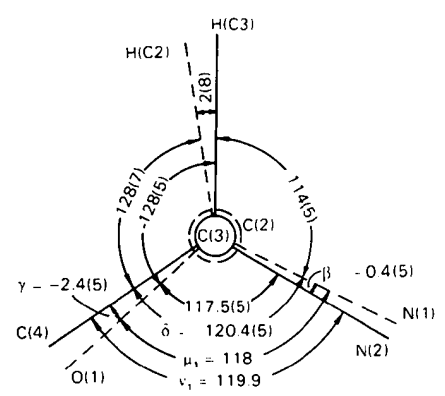

Fig. 2. Newman projection along $\mathrm{C}(2)-\mathrm{C}(3)$, illustrating the ring fusion (angles in deg). 
statistically significant: $\sum(\Delta / \sigma)^{2}=19.30\left(\chi^{2}\right.$ at $95 \%$ 7.81); however, this distortion is probably not real.

The phenyl ring is markedly twisted with respect to the imidazolidine plane. The dihedral angle between the least-squares planes through the phenyl and imidazolidine rings is $45.0(2)^{\circ}$. Values in the range $60-80^{\circ}$ for this dihedral angle have been found in similar compounds, except for the value of $15.1(6)^{\circ}$ observed in the case of $1^{\prime}$-phenyl-1', $3^{\prime}, 4^{\prime}, 5^{\prime}$-tetrahydro-1,2-dideoxyglucofuranoso[1,2-d]imidazol-2-one

(Conde, Bernier \& Márquez, 1980) and may indicate a significant contribution of intramolecular interaction. The ethyl group is also twisted with respect to the imidazolidine ring as indicated by the torsion angle $\mathrm{C}(1)-\mathrm{N}(2)-\mathrm{C}(15)-\mathrm{C}(16)=85.6(7)^{\circ}$.

\section{Crystal packing}

Fig. 3 shows the contents of the unit cell viewed down the $a$ axis. The crystal structure is stabilized by an extensive three-dimensional hydrogen-bonding network. Molecules are linked to form chains parallel to [100] by $\mathrm{O}(2)-\mathrm{H}(\mathrm{O} 2) \cdots \mathrm{O}(5)(x+1, y, z)$ hydrogen bonds and chains parallel to [010] by $\mathrm{C}(15)-$ $\mathrm{H}(151) \cdots \mathrm{O}(3)(x, y-1, z)$ hydrogen bonds. Also, each molecule is linked to three nearest neighbours related by a twofold screw axis by $\mathrm{O}(5)-\mathrm{H}(05) \cdots \mathrm{O}(2)(-x-1$, $\left.y+\frac{1}{2},-z-1\right), \mathrm{O}(4)-\mathrm{H}(\mathrm{O} 4) \cdots \mathrm{S}\left(-x, y+\frac{1}{2},-z-1\right)$ and $\mathrm{C}(4)-\mathrm{H}(4) \cdots \mathrm{O}(4)\left(-x-1, \quad y-\frac{1}{2}, \quad-z-1\right) \quad$ hydrogen bonds. Details of these hydrogen bonds are given in Table 2.

For the two $\mathrm{O}-\mathrm{H} \ldots \mathrm{O}$ contacts listed in Table 2 the values of the $d$ parameter, defined as the difference between the sum of the van der Waals radii and the interatomic distance (Taylor \& Kennard, 1982), are 0.36 and $0.66 \AA$ respectively, both satisfying the rule $d>0.3 \AA$, and the $\mathrm{O}-\mathrm{H} \cdots \mathrm{O}$ angles agree with the mean value $\left[165.8(12)^{\circ}\right]$ for bonds with $\mathrm{O} \cdots \mathrm{H}>$ $1.812 \AA$ (Allen, Kennard \& Taylor, 1983) and so can be described as hydrogen bonds. For the two short $\mathrm{C}-\mathrm{H} \cdots \mathrm{O}$ interactions shown in Table 2 the $d$ values are both close to the limiting value $d=0.3$; however, the $\mathrm{C}(4)-\mathrm{H}(4) \ldots \mathrm{O}(4)$ angle is close to the mean value

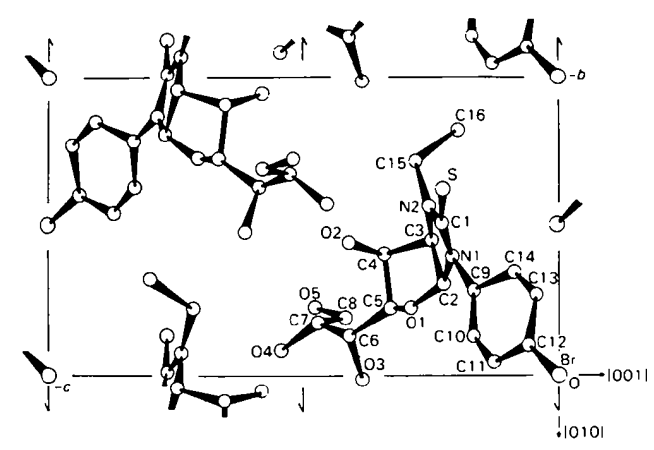

Fig. 3. A view of the cell down a.
Table 2. Geometry of the hydrogen bonds

$\begin{array}{cllll}X-\mathrm{H} \cdots Y & X \cdots Y(\AA) & X-\mathrm{H}(\AA) & \mathrm{H} \cdots Y(\AA) & X-\mathrm{H} \cdots Y\left({ }^{\circ}\right) \\ \mathrm{O}(2)-\mathrm{H}(\mathrm{O} 2) \cdots \mathrm{O}\left(5^{1}\right) & 3.094(6) & 0.86(9) & 2.34(9) & 182(8) \\ \mathrm{C}(15)-\mathrm{H}(15) \cdots \mathrm{O}\left(3^{11}\right) & 3.115(8) & 1.07(8) & 2.43(9) & 120(6) \\ \mathrm{O}(5)-\mathrm{H}(\mathrm{O} 5) \cdots \mathrm{O}\left(2^{\mathrm{il}}\right) & 2.986(7) & 0.96(9) & 2.06(10) & 161(8) \\ \mathrm{O}(4)-\mathrm{H}(\mathrm{O} 4) \cdots \mathrm{S}^{\mathrm{iv}} & 3.216(5) & 1.03(9) & 2.25(9) & 155(7) \\ \mathrm{C}(4)-\mathrm{H}(4) \cdots \mathrm{O}\left(4^{v}\right) & 3.304(7) & 0.97(8) & 2.44(8) & 148(6)\end{array}$

Symmetry transformations: (i) $x+1, y, z$; (ii) $x, y-1, z$; (iii) $-x-1, y+\frac{1}{2},-z-1$; (iv) $-x, y+\frac{1}{2},-z-1$; (v) $-x-1, y-\frac{1}{2},-z-1$.

reported for the $\mathrm{C}-\mathrm{H} \ldots \mathrm{O}$ hydrogen bonds (Taylor \& Kennard, 1982) but $\mathrm{C}(15)-\mathrm{H}(15) \cdots \mathrm{O}(3)$ is significantly smaller. On the other hand, $\mathrm{C}(15)$ is immediately adjacent to an $\mathrm{N}$ atom, this fact enhancing the facility to participate in hydrogen bonds (Taylor \& Kennard, 1982). The impotance of $\mathrm{C}-\mathrm{H} \ldots \mathrm{O}$ hydrogen bonds in the crystal structures of nucleosides has been recognized (Jeffrey \& Maluszynska, 1982). Finally, the existence of short $\mathrm{O}-\mathrm{H} \cdots \mathrm{S}$ contacts has been found in other imidazolidine-2-thione compounds (Vega, Hernández-Montis \& López-Castro, 1976; JiménezGaray, López-Castro \& Márquez, 1976; Criado, Conde \& Márquez, 1983) and, perhaps, the negative character associated with the $S$ atom in the resonance forms of the thiourea system is important in the electrostaticenergy term. No other intermolecular contacts significantly shorter than the sums of the van der Waals radii have been detected. The molecular geometry and crystal packing were computed by PARST (Nardelli, 1983).

The authors thank Professor Galbis for supplying the crystals and $\operatorname{Dr}$ Gutierrez-Puebla (University of Madrid) for collecting the data. The present work is part of a research project supported by the Government through the 'Comision Asesora de Investigación Cientifica y Técnica'.

\section{References}

Allen, F. H., Kennard, O. \& Taylor, R. (1983). Acc. Chem. Res. 16, 146-153.

Conde, A., Bernier, F. \& Màrquez, R. (1980). Acta Cryst. B36, 3048-3052.

Conde, A., López-Castro, A. \& MÁrquez, R. (1978). Rev. Iberoam. Cryst. Miner. Metalog. 1, 23-36.

Cremer, D. \& Pople, J. A. (1975). J. Am. Chem. Soc. 97, 1354-1358.

Criado, A., Conde, A. \& Márquez, R. (1983). Acta Cryst. C39, 122-125.

Duax, W. L., Weeks, C. M. \& Rohrer, D. C. (1976). Top. Stereochem. 9, 271-383.

Estrada, M. D., Conde, A. \& Márquez, R. (1983). Acta Cryst. C39, 1418-1421.

Galbis-Pérez, J. A., Palacios, J. C., Jiménez-Requejo, J. L., Avalos, M. \& Fernández-Bolaños, J. (1983). Unpublished results.

Galbis-Pérez, J. A., Pinto Corraliza, R. M., Román-Galán, E. \& GoMÉz-Guillén, M. (1979). An. Quím. 75, 387-391.

Garcia-Gonzalez, F., Galbis-Pérez, J. A., FernandezGARCIA-HiERro, J. I. \& FERNÁNDEZ-Bolaños, J. (1979). An Quim. 75, 1002-1004. 
Geise, H. J., Altona, C. \& Romers, C. (1967). Tetrahedron, 23, 439-463.

Hamilton, W. C. (1959). Acta Cryst. 12, 609-610.

Hamilton, W. C. (1965). Acta Cryst. 18, 502-510.

International Tables for X-ray Crystallography (1974). Vol. IV. Birmingham: Kynoch Press.

JefFrey, G. A. \& MAluszynSKA, H. (1982). Int. J. Biol. Macromol. 4, 173-185.

JimÉnEZ-Garay, R., López-Castro, A. \& Márquez, R. (1976). Acta Cryst. B32, 1367-1371.
NARdelli, M. (1983). Comput. Chem. 7, 95-98.

Stewart, J. M., Kundell, F. A. \& Baldwin, J. C. (1970). The $X R A Y$ system. Computer Science Center, Univ. of Maryland, College Park, Maryland.

TAYlOR, R. \& KenNard, O. (1982). J. Am. Chem. Soc. 104 5063-5070.

Valle, G., Cojazzi, G., Bussetti, V. \& Mammi, M. (1970). Acta Cryst. B26, 468-477.

Vega, R., Hernández-Montis, V. \& López-CAstro, A. (1976). Acta Cryst. B32, 1363-1366.

\section{SHORT COMMUNICATIONS}

Contributions intended for publication under this heading should be expressly so marked; they should not exceed about 1000 words; they should be forwarded in the usual way to the appropriate Co-editor; they will be published as speedily as possible.

Acta Cryst. (1984). C40, 901

Structure of 2-amino-3,5-dibromo- $N$-cyclohexyl- $N$-methylbenzenemethanamine-salicylic acid (1:1): corrigendum.* By Richard E. MARsh, Arthur Amos Noyes Laboratory of Chemical Physics, California Institute of Technology, Pasadena, California 91125, USA

(Received 8 A ugust 1983; accepted 15 September 1983)

\section{Abstract}

The crystal structure of $\mathrm{C}_{14} \mathrm{H}_{20} \mathrm{Br}_{2} \mathrm{~N}_{2} \cdot \mathrm{C}_{7} \mathrm{H}_{6} \mathrm{O}_{3}$ should be described in the monoclinic space group $C 2 / c$ rather than the triclinic $P \overline{1}$ reported by Shimizu, Nishigaki, Nakai \& Osaki [Acta Cryst. (1983), C39, 891-893].

The crystal structure of this compound was described as triclinic, space group $P \overline{1}$, with $a=29.146(34), \quad b=$ 9.710 (3), $c=9.719$ (9) $\AA, \alpha=105.18$ (5), $\beta=124.18$ (6), $\gamma=85.99(6)^{\circ}, Z=4$ (Shimizu, Nishigaki, Nakai \& Osaki, 1983). The vectors [011], [011], [102] define a $C$-centered cell with $a^{\prime}=15.433, b^{\prime}=11.803, c^{\prime}=24.306, \alpha^{\prime}=89.97$, $\beta^{\prime}=99.11, \gamma^{\prime}=90.06^{\circ}, Z=8$. $\dagger$ The corresponding transformations $x^{\prime}=x+\frac{1}{2}(y-z), y^{\prime}=-x+\frac{1}{2}(y+z), z^{\prime}=x$ lead to atomic coordinates that are consistent with the symmetry of the monoclinic space group $C 2 / c$ within the reported uncertainties. (No translation of origin is necessary since, by even chance, the center of symmetry chosen as origin in the triclinic description corresponds to a conventional origin in $C 2 / c$.) The $C 2 / c$ parameters are given in Table 1 .

The $c$-glide plane of $C 2 / c$ requires the systematic extinction of reflections $h k \bar{k}$ with $h$ odd in the triclinic indexing.

\footnotetext{
* Contribution No. 6876 from the Arthur Amos Noyes Laboratory of Chemical Physics. This work was supported in part by National Institutes of Health Research Grant No. GM 16966.

$\dagger$ The relative e.s.d.'s in the triclinic cell translations are highly disparate, and since covariances are not given it is impossible even to estimate appropriate e.s.d.'s for the monoclinic cell dimensions.
}

Table 1. Coordinates $\left(\times 10^{4}\right)$ for space group $C 2 / c$

The $P$ I coordinates (Shimizu et al., 1983) have been averaged according to the symmetry of $C 2 / c$; numbers in square brackets are shifts necessary to achieve this symmetry.

$\begin{array}{lccc} & x^{\prime} & y^{\prime} & z^{\prime} \\ \operatorname{Br}(1) & 612[1] & 5140[0] & 4352[0] \\ \mathrm{Br}(2) & 432[0] & 695[1] & 3513[1] \\ \mathrm{C}(1) & 1077[2] & 3766[12] & 2860[0] \\ \mathrm{C}(2) & 996[8] & 4556[6] & 3276[2] \\ \mathrm{C}(3) & 760[10] & 4137[3] & 3768[2] \\ \mathrm{C}(4) & 604[2] & 3002[2] & 3856[4] \\ \mathrm{C}(5) & 673[6] & 2265[9] & 3425[8] \\ \mathrm{C}(6) & 908[4] & 2623[3] & 2935[4] \\ \mathrm{N}(1) & 1164[1] & 5692[3] & 3220[2] \\ \mathrm{C}(7) & 1299[4] & 4099[2] & 2306[0] \\ \mathrm{N}(2) & 2225[1] & 3768[1] & 2252[0] \\ \mathrm{C}(8) & 2878[4] & 4586[1] & 2543[2] \\ \mathrm{C}(9) & 2363[6] & 3544[4] & 1658[4] \\ \mathrm{C}(10) & 2074[4] & 4540[0] & 1276[2] \\ \mathrm{C}(11) & 2233[2] & 4270[0] & 686[0] \\ \mathrm{C}(12) & 1755[2] & 3196[6] & 469[2] \\ \mathrm{C}(13) & 2055[2] & 2215[2] & 856[6] \\ \mathrm{C}(14) & 1917[2] & 2448[2] & 1454[0] \\ \mathrm{C}(15) & 3847[1] & 2707[5] & 3684[2] \\ \mathrm{C}(16) & 4724[2] & 3022[4] & 3882[2] \\ \mathrm{C}(17) & 4938[10] & 3469[3] & 4411[1] \\ \mathrm{C}(18) & 4294[5] & 3621[5] & 4736[2] \\ \mathrm{C}(19) & 3423[4] & 3333[5] & 4549[0] \\ \mathrm{C}(20) & 3207[2] & 2865[5] & 4021[0] \\ \mathrm{C}(21) & 3609[1] & 2233[3] & 3114[2] \\ \mathrm{O}(1) & 2826[2] & 2039[4] & 2930[2] \\ \mathrm{O}(2) & 4222[0] & 2059[3] & 2846[2] \\ \mathrm{O}(3) & 5348[2] & 2897[1] & 3558[0] \\ & & & \end{array}$

\section{Reference}

Shimizu, N., Nishigaki, S., Nakai, Y. \& Osaki, K. (1983). Acta Cryst. C39, 891-893.

(C) 1984 International Union of Crystallography 